\author{
Janusz Feczko \\ Uniwersytet Pedagogiczny \\ im. Komisji Edukacji Narodowej \\ w Krakowie
}

\title{
Gospodarka agroturystyczna - aspekty ekonomiczne i zarządcze
}

Niepełna wiedza na temat stanu gospodarstw agroturystycznych w Polsce, w tym również w województwie świętokrzyskim, spowodowała konieczność wykonania diagnostycznych badań empirycznych źródeł pierwotnych. Dotychczasowe prace dotyczące agroturystyki w Polsce polegały na gromadzeniu informacji z urzędów gmin (źródła wtórne), co istotnie pomniejszało ich wiarygodność $\mathrm{w}$ istniejącej specyfice polskiej wsi. Z tego powodu również świadomie odstąpiono od badań różnego rodzaju stowarzyszeń, inicjatyw i innych organizacji agroturystycznych. W 2009 roku objęto badaniem 247 gospodarstw agroturystycznych województwa świętokrzyskiego, na ogólną liczbę 350 jednostek (tab. 1).

Reprezentatywna próba badawcza odzwierciedlała działające gospodarstwa agroturystyczne we wszystkich powiatach. Badania wykonano poprzez wywiad. Ankieterzy posługując się zweryfikowanym kwestionariuszem ankietowym przeprowadzali badania na terenie gospodarstw agroturystycznych, jednocześnie naocznie weryfikując dane badawcze. Wywiady przeprowadzono z osobami prowadzącymi gospodarstwa agroturystyczne, które oceniały w skali pięciopunktowej znaczenie poszczególnych zagadnień.

Tab. 1. Charakterystyka respondentów - prowadzących gospodarstwa agroturystyczne

\begin{tabular}{|c|c|c|}
\hline \multirow{4}{*}{ Płeć } & kobiety & $66,3 \%$ \\
\cline { 2 - 3 } & mężczyźni & $33,7 \%$ \\
\hline \multirow{4}{*}{ Wykształcenie } & podstawowe & $1,3 \%$ \\
\cline { 2 - 3 } & średnie niepełne & $12,6 \%$ \\
\cline { 2 - 3 } & średnie pełne & $60,5 \%$ \\
\cline { 2 - 3 } & wyższe niepełne & $10,9 \%$ \\
\cline { 2 - 3 } & wyższe pełne & $14,7 \%$ \\
\hline \multirow{4}{*}{ Miejsce zamieszkania } & miasto powiatowe & $2,5 \%$ \\
\cline { 2 - 3 } & małe miasto & $8,9 \%$ \\
\cline { 2 - 3 } & wieś & $88,6 \%$ \\
\hline \multirow{4}{*}{ Wiek } & $18-25$ & $1,6 \%$ \\
\cline { 2 - 3 } & $26-35$ & $10,2 \%$ \\
\cline { 2 - 3 } & $36-45$ & $33,5 \%$ \\
\cline { 2 - 3 } & $46-55$ & $42,0 \%$ \\
\cline { 2 - 3 } & $56-65$ & $9,0 \%$ \\
\cline { 2 - 3 } & 66 i więcej & $3,7 \%$ \\
\cline { 2 - 3 } & &
\end{tabular}

Źródło: opracowanie własne. 
Z gospodarstw agroturystycznych najwięcej korzystali turyści krajowi (ryc. 1). Turyści zagraniczni stanowili nikłą część turystów, przy pozytywnie nastawionych gestorach bazy. Powoduje to zasadniczość ukierunkowania produktu, jak też komunikacji marketingowej na turystę zagranicznego. Najważniejszym segmentem turystów były rodziny z dziećmi i młodzież - grupy osób w wieku 19-59 lat. Potencjalne możliwości tworzył nikły udział młodzieży i dzieci do 11. roku życia, dla których organizowane są tzw. zielone szkoły i innego rodzaju pobyty. Wbrew obiegowym opiniom z gospodarstw agroturystycznych prawie w ogóle nie korzystali pielgrzymi i osoby duchowne.

Prowadzącymi gospodarstwa agroturystyczne najczęściej były kobiety posiadające średnie wykształcenie, mieszkające na wsi, w przedziale wieku 46-55 lat. Dane te wskazują wybór środków i zakresów oddziaływania aktywizacji tych osób, jak też optymalizacji kierowania gospodarstwami agroturystycznymi.

Ryc. 1. Turyści nocujący w gospodarstwach agroturystycznych i korzystający z ich usług

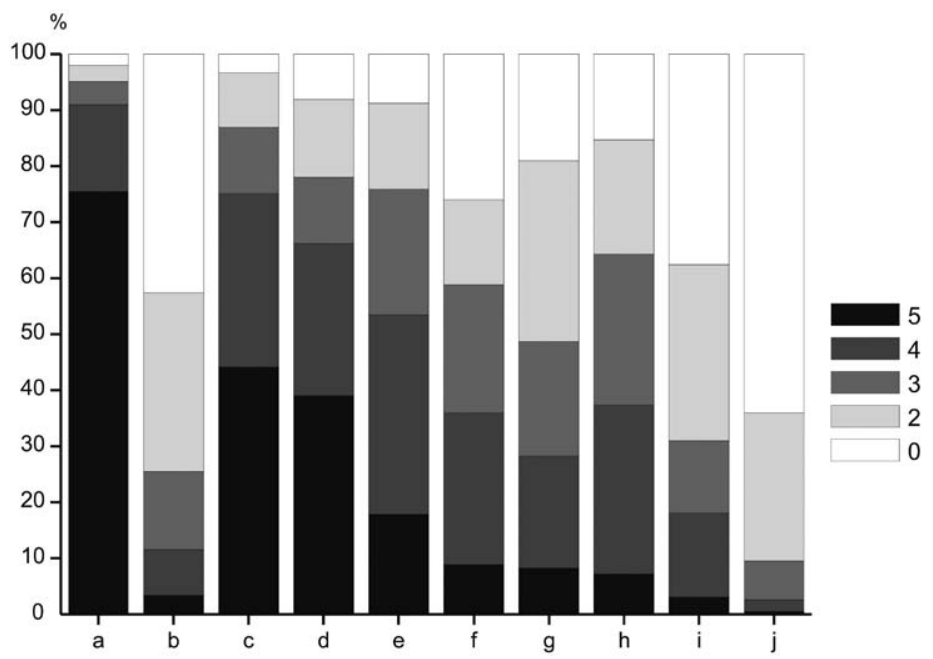

Skala: 5 - w największym zakresie; 4 - korzystają średnio; 3 - jest ich mało; 2 - sporadycznie; 0 - brak turystów

a - Turyści krajowi - Polacy; b- Turyści zagraniczni; c- Rodziny z dziećmi i młodzieża;

d - Grupy osób (w wieku od 19-59 lat); e - Turyści seniorzy (60 lat i więcej); $f$ - Dzieci (do 11 lat);

g- Pojedyncze osoby (powyżej 19 lat); h - Młodzież (12-18 lat); i - Biznesmeni;

j- Osoby duchowne i kultów religijnych, pielgrzymi

Źródło: badania własne.

Dyskusyjna jest kategoryzacja bazy agroturystycznej przyjęta przez PFTW „Gospodarstwa Gościnne": pokoje gościnne, samodzielne jednostki mieszkalne, kwatery grupowe, przyzagrodowe pola kempingowe (z podziałem na stopnie jakości lub (pod) kategorie).

Najczęściej turyści odbywali piesze wędrówki i spacery, zadowalając się swojskim klimatem (ryc. 2). Istotnymi były oczekiwania turystów co do polepszenia ich stanu zdrowia (według turystów baza rekreacyjno-sportowa powinna być rozbudowana). Zainteresowania turystów wiązały się z turystyką kulturową i rowerową (wytyczenie i rozwój szlaków pieszych i rowerowych). Pobyt w tym rejonie nie dotyczył osób niepełnosprawnych (niewykorzystany walor wielowymiarowości produktu turystycznego), turystyki specjalistycznej i związanej z techniką. 
Ryc. 2. Z czego korzystają turyści przebywający w gospodarstwach agroturystycznych na terenie ziemi świętokrzyskiej

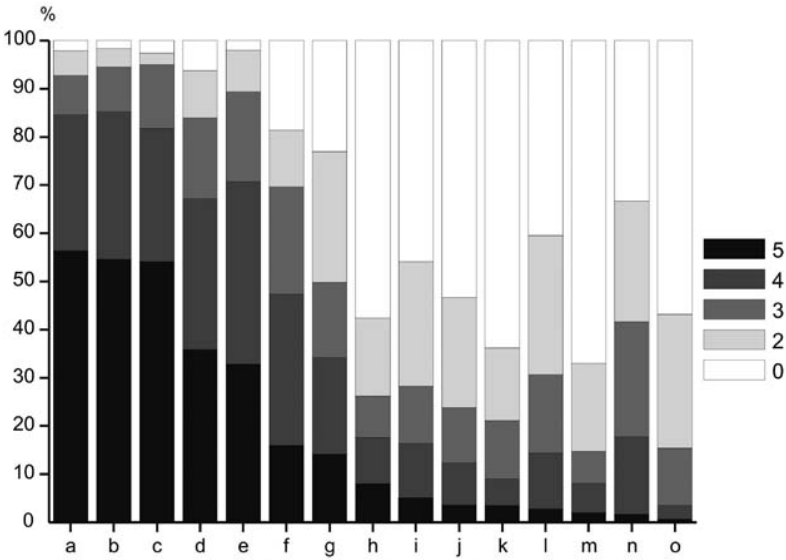

Skala: 5 - najwięcej; 4 - korzystają średnio; 3 - korzystają mało; 2 - sporadycznie; 0 - nie korzystają

a - Turystyka piesza; b - Swojskie klimaty: agroturystyka; c - Polepszenie zdrowia (spacery, wędrówki, rekreacja, sporty, odpoczynek i inne); d - Turystyka kulturowa (zabytki, zamki, pałace, małe historyczne miasteczka, itp.); e - Turystyka rowerowa; $\mathrm{f}$ - Ośrodki kultu, sanktuaria, święte miejsca, relikwie; $\mathrm{g}$ - Inne formy turystyki aktywnej (konna, kajakowa, sporty zimowe, itp.); $\mathrm{h}$ - Poratowanie zdrowia (zabiegi lecznicze); i - Targi; j - Praca, biznes; k - Zielona szkoła - edukacja dzieci i młodzieży; I - Techniki m - Turystyka specjalistyczna (wspinaczkowa, sporty lotnicze, spływy kajakowe i inne); n - Szlaki literackie, architektury obronnej, drewnianej; o - Turystyka niepelnosprawnych

Źródło: badania własne.

Decydujące dla pozyskania lojalnych agroturystów są miejscowe atrakcje turystyczne, zorganizowane i zatrudniające pracowników do obsługi turystów (ryc. 3). Najpopularniejsze z nich to: Park Dinozaurów JuraPark Bałtów (figury prehistorycznych zwierząt naturalnych rozmiarów, spływ rzeką i inne), jaskinie oraz imprezy plenerowe. Niewykorzystanym bogactwem wydają się unikalne pracownie rękodzieła, ekspozycje (np. ziół), a także wystawcy o zmiennych ekspozycjach.

Ryc. 3. Jak oceniają działające atrakcje ziemi świętokrzyskiej turyści przebywający w gospodarstwach agroturystycznych i korzystając $z$ ich usług

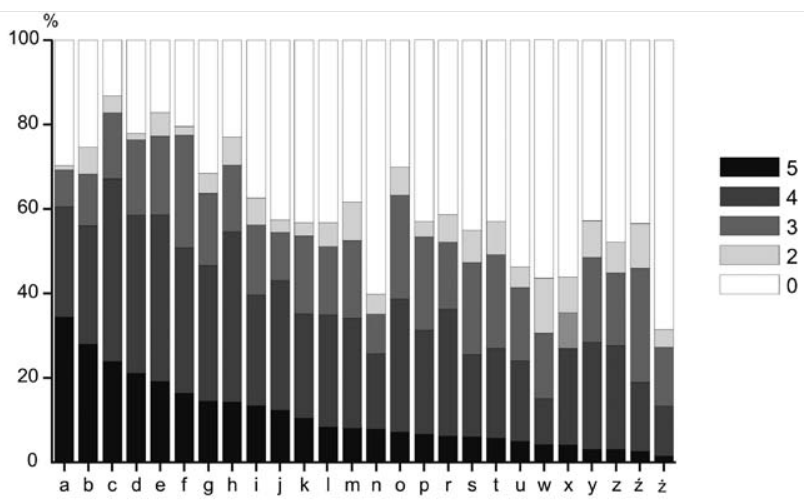

Skala: 5 - wspaniale; 4 - dobre; 3 - dostateczne; 2 - złe; 0 - brak oceny turystów

a - Park Jurajski Bałtów; b - Jaskinie; c - Imprezy plenerowe; d - Obiekty kultu religijnego; e - Zamki

i palace; $\mathrm{f}$ - Dworki; $\mathrm{g}$ - Ogrody; $\mathrm{h}$ - Muzea; i - Ośrodki tradycji (np. garncarstwa itp.) j - Kluby muzyczne;

k - Parki etnograficzne; I - Zabytkowe zagrody; m - Wystawy; $n$ - Podziemne trasy turystyczne;

o - Centra kultury; $\mathrm{p}$ - Galerie; $r$ - Kina; $s$ - Izby pamięci; $t$ - Izby pamięci; $u$ - Izby regionalne

i etnograficzne; w - Ekspozycje (np. ziól itp.); x - Teatry; y - Biblioteki; z - Domy kultury; ź - Biura

wystaw artystycznych; ż - Pracownie (np. gobelinów itp.)

Źródło: badania własne. 
W zakresie materialnych atrakcji turystycznych podkreślano dobroczynny wpływ zdrowego powietrza, wody i ziemi (ryc. 4). Uzupełniały to obfite lasy oraz osobliwości przyrody. Nikłym, niedocenianym zainteresowaniem darzono architekturę miejską, której świętokrzyskie perełki są znaczące w historii sztuki.

Ryc. 4. Jak turyści przebywający w gospodarstwach agroturystycznych i korzystający z ich usług oceniają materialne atrakcje turystyczne

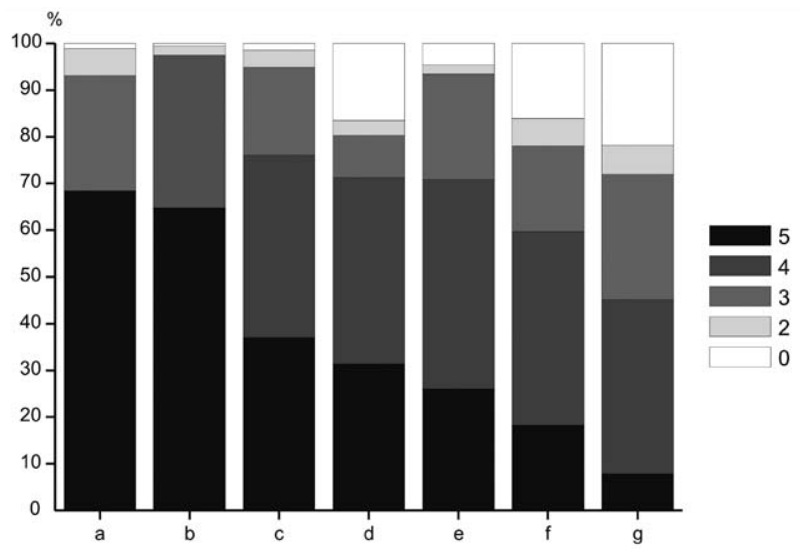

Skala - 5 wspaniale; 4 - dobre; 3 - dostateczne; 2 - złe; 0 - brak oceny turystów

a - Zdrowe otoczenie (czyste powietrze, woda, ziemia); b - Lasy; c - Osobliwości przyrody;

d-Góry; e - Zabudowa wiejska; f - Obszary równinne; $\mathrm{g}$ - Architektura miejska

Źródło: badania własne.

Transport został uznany za wygodny i łatwy w przypadku korzystania przez turystów z własnych aut (ryc. 5), ale dojazdy do miejsc atrakcji turystycznych środkami komunikacji publicznej wywoływały już wiele skarg.

Ryc. 5. Jak turyści oceniają dojazd do gospodarstw agroturystycznych i przejazdy do miejsc atrakcji turystycznych

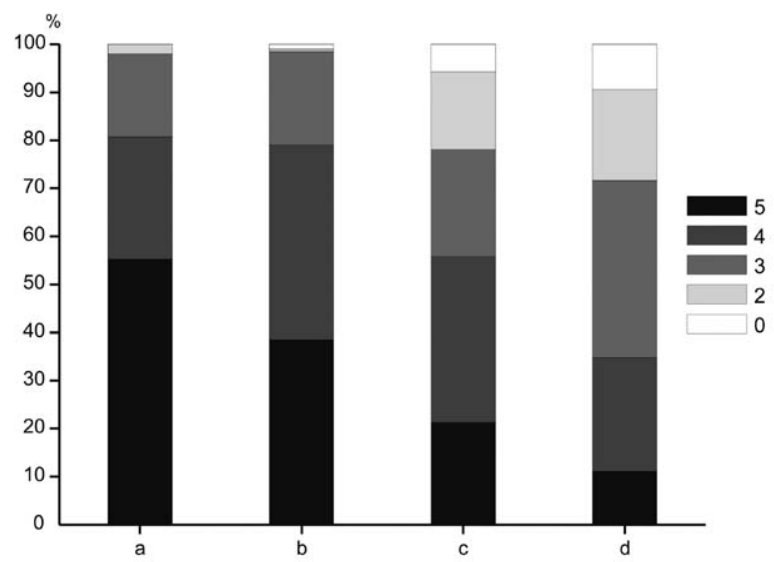

Skala: 5 - bardzo wygodny i łatwy; 4 - wygodny i łatwy; 3 - dostatecznie wygodny i łatwy; 2 - niewygodny i niełatwy; 0 -brak transportu

a - Dojazd od Pana/i obiektu autem turystów; b - Przejazd z Pana/i obiektu do atrakcji turystycznych autem turystów; c - Dojazd do Pana/i obiektu publicznymi środkami komunikacji (PKS, PKP, busy, itp.) $\mathrm{d}$ - Przejazd do atrakcji turystycznych z Pana/i obiektu publicznymi środkami komunikacji

Źródło: badania własne. 
Agroturyści najwyżej oceniali przyjazny klimat, uprzejmość i życzliwość ludzi, gdzie życzliwość określano jako bezinteresowne pozytywne nastawienie (ryc. 6). Podkreślano też możliwość spędzania urlopu w mało zatłoczonym miejscu, przy wysokim poziomie bezpieczeństwa. Negatywnie oceniano politykę cenową dostępu do atrakcji, koszty dojazdów i niedorozwój usług towarzyszących.

Ryc. 6. Jak turyści korzystający z gospodarstw agroturystycznych oceniają atrakcje ziemi świętokrzyskiej

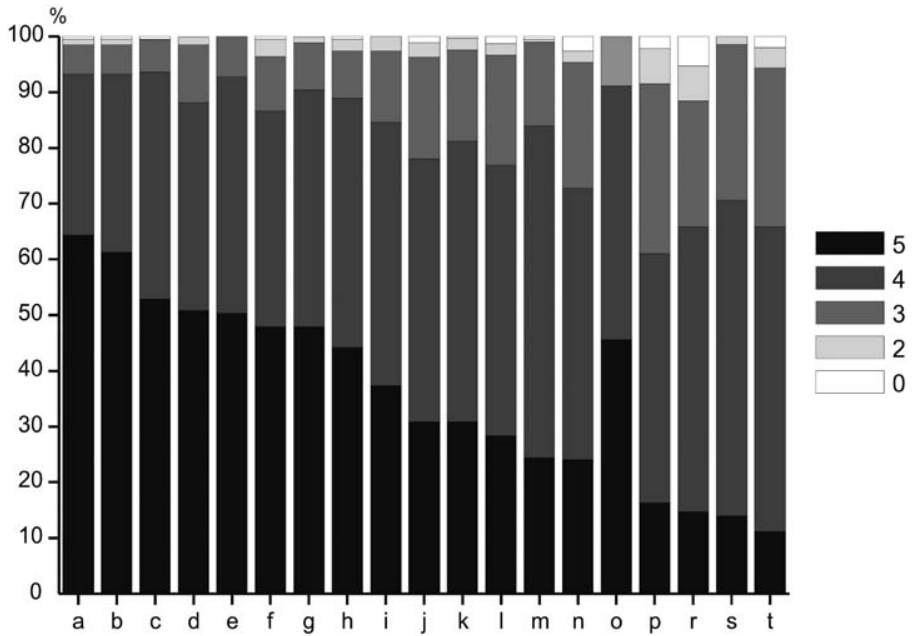

Skala: 5 - bardzo dobrze; 4- dobrze; 3 - dostatecznie; 2 - źle; 0 - jako bardzo złe

a - Przyjazny klimat; b - Uprzejmość i życzliwość ludzi; c - Życzliwość ludzi; d - Możliwość podróży i wypoczynku bez tłoku; e - Bezpieczeństwo infrastruktury; f - Gastronomia;

g - Bezpieczeństwo obsługi; h - Obsługa turystów przez pracowników (organizacja ich pracy);

i - Czystość i stan sanitarny; j - Interesujące towarzystwo innych turystów; k - Oryginalność,

unikalność; I - Wartość (jakość); m - Poziom cenowy przebywania w regionie świętokrzyskim;

n - Dostępność - godziny otwarcia; o - Dostępność informacji o atrakcjach na odległość;

p - Dostępność komunikacyjna; r - Usługi towarzyszące (opieka nad dziećmi, sklepy, usługi,

pamiatki, folklor, itp.); s - Poziom cenowy dojazdu; $\mathrm{t}$ - Poziom cenowy oglądu, korzystania

$\mathrm{z}$ atrakcji (bilety, przewodniki, itp.)

Źródło: badania własne.

Swojskie klimaty, tak charakterystyczne dla gospodarstw agroturystycznych, turyści kojarzyli głównie z kontaktem z naturą i przyrodą, wypoczynkiem - odnową fizyczną i psychiczną, a także przebywaniem w towarzystwie życzliwych i uczynnych gospodarzy (ryc. 7). Podkreślano możliwość kontaktu ze wsią, ale bez czynnego udziału w funkcjonowaniu gospodarstwa wiejskiego. Swojskie klimaty negatywnie kojarzono z cenami produktów, przejazdami, specyficznym wystrojem gospodarstwa agroturystycznego i usługami towarzyszącymi. Ekspozycja materialnego lokalnego dziedzictwa kulturowego w skali pojedynczego gospodarstwa wydaje się niedoceniana. 
Ryc. 7. Z czym kojarzą swojskie klimaty agroturystyki turyści przebywający w gospodarstwach agroturystycznych, korzystający z ich usług

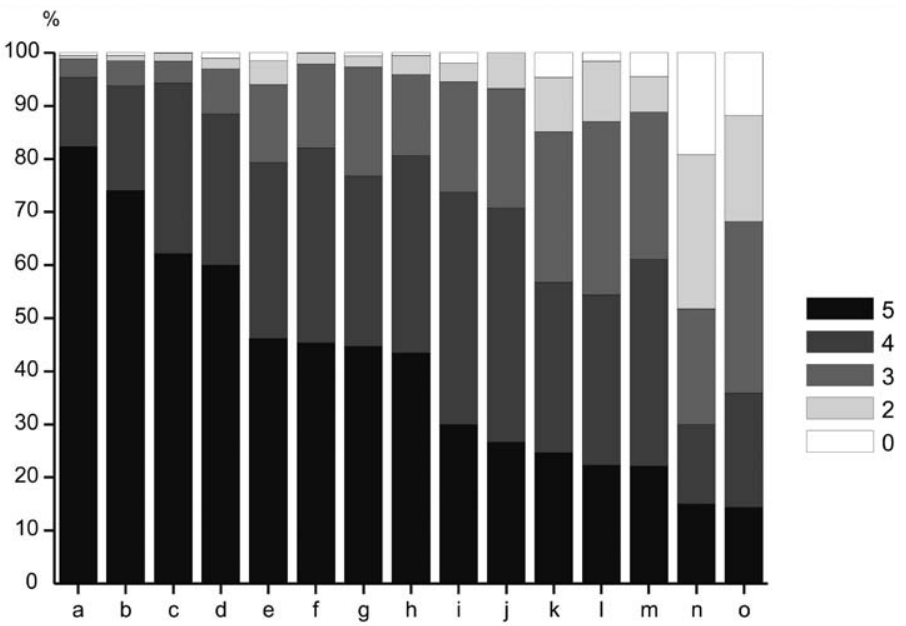

Skala: 5 - w bardzo wysokim stopniu; 4 - wiążą się z....; 3 - czasem kojarzą z...

2 - nie kojarza; 0 - nie wiedzą o związku swojskiego klimatu z wymienionymi możliwościami

a - Kontakt z natura, przyroda; b - Wypoczynek, odnowa fizyczna i psychiczna (spokój, cisza); c - Przebywanie w towarzystwie życzliwych, uczynnych gospodarzy; d - Zdrowe, smaczne, regionalne jedzenie, e - Kontakt ze wsia bez czynnego udziału z funkcjonowaniem gospodarstwa wiejskiego; f - Moźliwość swobodnego zachowania się poza miejscem stałego zamieszkania; g - Kontakt z kultura wiejską folklorem, h - Możliwość intensywnego biesiadowania, zabawy; i - Korzystanie z atrakcji turystycznych regionu poza miejscowością z gospodarstwem agroturystycznym; j - Korzystanie z atrakcji turystycznych w Twojej miejscowości; k - Usługi towarzyszace (plac zabaw, opieka nad dziećmi, rekreacja, przejazd bryczka, jeździectwo itp.); I - Folklorystyczny, specyficzny wystrój gospodarstwa agroturystycznego; m - Niższe ceny w stosunku do innych obiektów noclegowych turystycznych; $n$ - Dowożenie, przejazdy środkiem transportu należącym do gospodarstwa agroturystycznego; o - Udział w pracach gospodarstwa rolnego

Źródło: badania własne.

Powszechna staje się opinia, że głównym celem prowadzenia agroturystyki jest pozyskanie przychodów finansowych (ryc. 8). Dotychczas w większości przypadków przychody z gospodarstw agroturystycznych dostarczały mniej niż połowy kosztów utrzymania tych jednostek. Pożyczki były uzupełnieniem innych przychodów gestorów bazy agroturystycznej.

Większość osób prowadzących gospodarstwa agroturystyczne określiło swoją przyszłość jako nadal związaną z agroturystyką (ryc. 9a). Jako największe przeszkody w rozwoju gospodarstw agroturystycznych wskazano brak wystarczających środków finansowych, dochodów, brak pomocy gminy, wysokie podatki, wadliwe przepisy (ryc. 9b). W opinii badanych nie były przeszkodami: nieodpowiednia obsługa turystów, wysokie ceny, nieatrakcyjne otoczenie, słaby, niekonkurencyjny produkt itp. Wskazuje to po części na roszczeniową postawę wobec otoczenia, przy jednocześnie mało samodzielnej i kreatywnej działalności. 
Ryc. 8. Czym są dochody z agroturystyki dla prowadzących gospodarstwa agroturystyczne rodzin/gospodarstw domowych

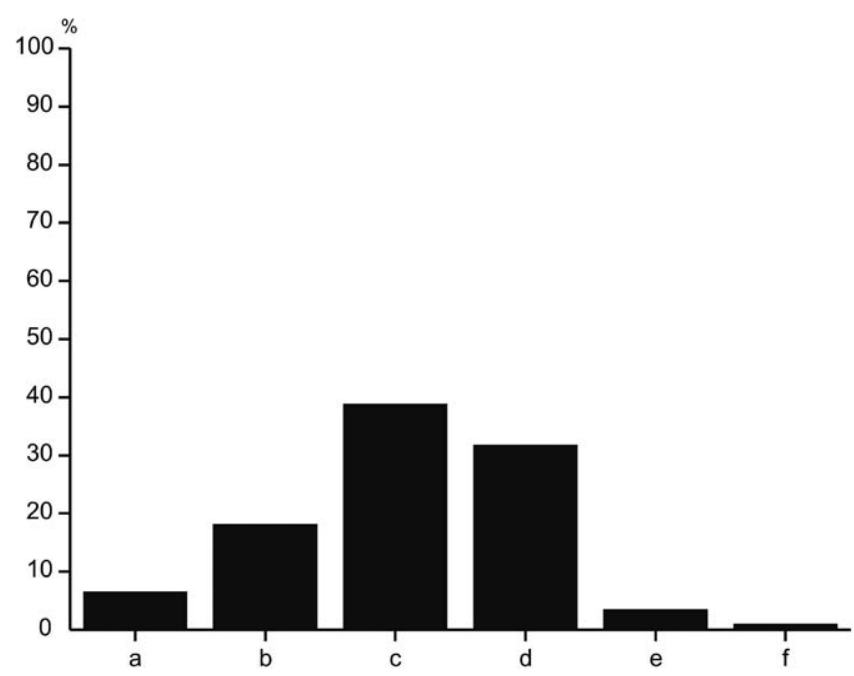

a - głównym źródłem utrzymania, gospodarstw agroturystycznych;

b - dostarczają powyżej połowy kosztów utrzymania gospodarstw agroturystycznych;

c - dostarczaja około 20 - $49 \%$ kosztów utrzymania gospodarstw agroturystycznych;

d - dostarczają kilka procent kosztów utrzymania gospodarstw agroturystycznych;

e - nie dostarczają zysku, a koszty pochlaniaja przychody gospodarstw agroturystycznych;

f - koszty są znacznie wieksze od przychodów gospodarstw agroturystycznych;

Źródło: badania własne.

Ryc. 9a. Zamiary prowadzących gospodarstwa agroturystyczne w zakresie rozwoju agroturystyki/turystyki wiejskiej

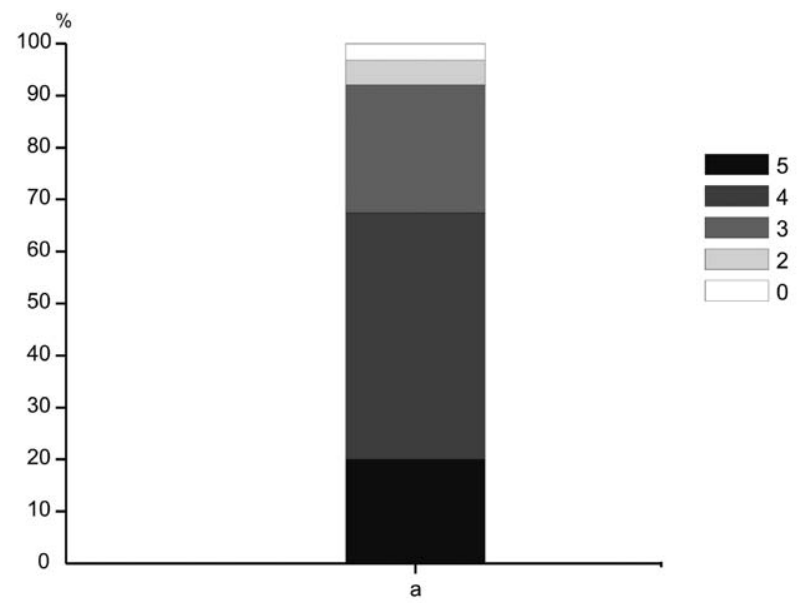

Skala: 5 - jestem bardzo pewny; 4 - będę prowadził; 3 - zastanawiam się; 2 - nie będę prowadził; 0 - już zrezygnowałem

Źródło: badania własne. 
Ryc. 9b. Przeszkody w rozwoju gospodarstw agroturystycznych i turystyki wiejskiej określone przez osoby tworzące produkty agroturystyczne

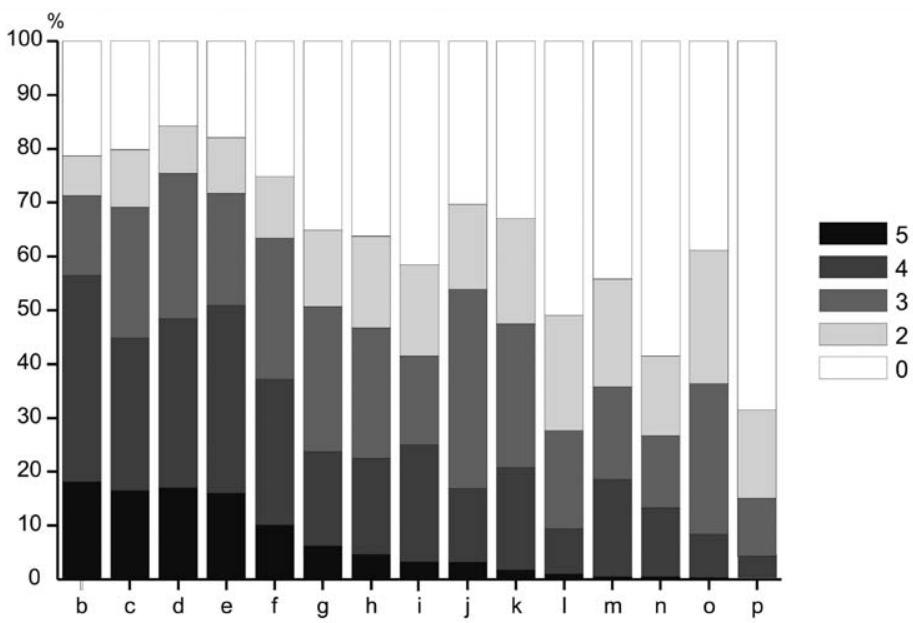

Skala: 5 -główne, decydujące przyczyny; 4 - ważne przyczyny; 3 - przyczyny mało ważne; 2 - przyczyny nie ważne; 0 - takie przyczyny w ogóle nie występują

\section{b - Brak finansów na rozwój biznesu; c - Brak dochodu dla właściciela gospodarstwa} agroturystycznego; d - Brak pomocy gminy, instytucji; e - Zbyt wysokie podatki i inne obowiazkowe obciążenia finansowe; $f$ - Wadliwe przepisy, prawne wymagania; $g$ - Nieodpowiednia baza materialna gospodarstwa agroturystycznego; $\mathrm{h}$ - Zła informacja, reklama o produkcie gospodarstwa agroturystycznego; i - Wyniszczająca konkurencja; j - Brak przyjaznego klimatu dla biznesu; k - Słaby nie konkurencyjny produkt turystyczny gospodarstwa agroturystycznego;

I - Brak profesjonalnych umiejętności prowadzenia biznesu; m - Brak pomysłu na aktywizację działalności gospodarstwa agroturystycznego; $n$ - nieatrakcyjne otoczenie turystyczne;

o - Za wysokie ceny produktu gospodarstwa agroturystycznego; p - Nieodpowiednia obsługa turystów w gospodarstwie agroturystycznym

Źródło: badania własne.

Agroturystyka ziemi świętokrzyskiej wymaga istotnych zmian. Analiza konsumpcji agroturystycznej i zarządzania gospodarstwami agroturystycznymi w tym regionie dowodzi potrzeby większego ukierunkowania na dochodowego turystę zagranicznego. Ponadto wskazane jest poszerzenie oferty podaży w zakresie obsługi rodzin, młodzieży i dzieci.

Turyści korzystający z gospodarstw agroturystycznych oczekiwali polepszenia bazy rekreacyjno-sportowej, wytyczenia i rozwoju szlaków turystycznych pieszych oraz rowerowych. Rozwojowa część potencjału agroturystyki związana jest z materialnym lokalnym dziedzictwem kulturowym, w tym też z unikalnymi pracowniami rękodzieła. Mankamentem była głównie niewygodna i stosunkowo droga komunikacja do miejsc atrakcji turystycznych.

Przychody z agroturystyki właścicieli gospodarstw agroturystycznych najczęściej pokrywały mniej niż połowę kosztów utrzymania tych jednostek. W sytuacji braku dostępności tanich kredytów i innych środków finansowych, jest to jedną z głównych przyczyn braku dalszego rozwoju agroturystyki w tym regionie.

Otrzymane wyniki badań mogą być przydatne w celowych zmianach gospodarki agroturystycznej i dalszym, rozwojowym zarządzaniu tym regionem. 


\section{Literatura}

1. Sawicki B., Agroturystyka w aktywizacji obszarów wiejskich, Lublin 2007, s. 260.

2. Sikora J., Organizacja ruchu turystycznego na wsi, WSiP, Warszawa 1999, s. 256.

3. Sznajder M., Przezbórska L., Agroturystyka, PWE, Warszawa 2006, s. 257.

4. http://www.agroturystyka.pl./36097-37-agroturystyka

5. http://www.wakacje.agro.pl/newsa/pokuz.php?id=4

6. http://www.witrynawiejska.org.pl/strona.php? $\mathrm{p}=443$

\section{Agrotouristic Economy - Management and Economic Aspects}

Through lack of agritourism realistic knowledge are important present and future original research by Association of Tourism, Hotel and Gastronomy Education and Research, in the economic and management fields. Świętokrzyskie (Poland) region to has ready tourism potential. It is needed the creative development of agritourism farms management. The goverumental and territorial administration, and the other organization support has to be optimized. 